DOI: https://doi.org/10.35961/jppmkepri.v1i1.170

\title{
Program Pengabdian Masyarakat Dalam Bentuk Penyuluhan Hukum Perkawinan Sirri Online dan Regulasi Menag Tentang Pencegahan Covid-19 di Lingkungan KUA Pada Masyarakat Tanjungpinang
}

\author{
Zulfa Hudiyani ${ }^{1 *}$, Rizki Pradana Hidayatullah ${ }^{2}$, Ahmad Jalili ${ }^{3}$, Amrul Lutfi ${ }^{4}$, \\ M. Arbisora Angkat ${ }^{5}$ \\ 1, 2, 3, 4, 5 STAIN Sultan Abdurrahman Kepulauan Riau, Bintan, Kepulauan Riau, 29123, Indonesia \\ *zulfa_hudiyani@stainkepri.ac.id
}

\begin{abstract}
Abstrak
Pengabdian kepada masyarakat dalam bentuk penyuluhan hukum dilakukan sebagai sosialisasi atas surat edaran Dirjen Bimas Islam No. P-003 Perubahan SE Dirjen Bimas Islam No. P-002 tentang pelaksanaan protokol penanganan Covid-19 pada area publik di lingkungan Direktorat Jenderal Bimbingan Masyarakat Islam. Diantara salah satu ketentuannya mengatakan bahwa permohonan pelaksanaan akad nikah di masa darurat Covid-19 untuk pendaftaran baru tidak dilayani serta meminta masyarakat untuk menunda pelaksanaannya. Regulasi ini berdampak pada kondisi calon pasangan pengantin yang mengalami kekecewaan. Diantaranya adalah kerugian materi karena banyak calon pengantin yang sudah mempersiapkan segala persiapan pernikahan secara maksimal. Mulai dari pemesanan gedung pernikahan, catering, dan tenda serta baju pengantin. Akibat dari regulasi ini, banyak juga calon pengantin yang tetap ingin melangsungkan pernikahan via online. Penyuluhan hukum ini bermanfaat untuk memberikan pemahaman kepada masyarakat tentang dampak hukum nikah sirri online. Oleh karena itu, penyuluhan ini tetap dipilih dan dilaksanakan di Tanjungpinang, khususnya pada jamaah mushalla Nurul Mubin Jl. Adi Sucipto Batu 10 Perumahan Mutiara Bintan RT.08/ RW 01, Kelurahan Pinang Kencana, Kecamatan Tanjung Pinang Timur, Kota Tanjungpinang dengan metode pretest tentang SE Dirjen Bimas Islam No. P-003 dan akibat dari perkawinan sirri online, ceramah keagamaan mengenai hukum perkawinan sirri online dalam perspektif hukum Islam dan hukum positif serta dampaknya, post test, diskusi dan konsultasi hukum yang dilakukan melalui via daring. Sehingga kesimpulan dari penyuluhan ini adalah semakin tinggi tingkat pengetahuan dan pemahaman masyarakat tentang dampak hukum nikah sirri online maka semakin berkurang hasrat dan keinginan seseorang untuk melakukannya.
\end{abstract}

Kata kunci: Nikah sirri online; Hukum Islam; Covid-19. 


\begin{abstract}
Community service in the form of legal counseling is carried out as a socialization of the circular of the Director General of Islamic Community Guidance No. P-003 Change of Circular Letter of Director General of Islamic Community Guidance No. P-002 regarding the implementation of the protocol for handling Covid-19 in public areas within the Directorate General of Islamic Community Guidance. One of the provisions states that the application for the implementation of the marriage contract during the Covid-19 emergency period for new registration is not served and asks the public to postpone its implementation. This regulation has an impact on the condition of the prospective bride and groom who experiences disappointment. Among them are material losses because many prospective brides have prepared all their wedding preparations to the fullest. Starting from ordering the wedding hall, catering, and tents and wedding clothes. As a result of this regulation, many prospective brides still want to get married via online This legal counseling is useful to provide an understanding to the public about the legal impact of online sirri marriage. Therefore, this counseling was still selected and carried out in Tanjungpinang, especially at the congregation mushalla Nurul Mubin Jl. Adi Sucipto Batu 10 Mutiara Bintan Housing RT.08 / RW 01, Pinang Kencana Village, Tanjung Pinang Timur District, Tanjungpinang City using the pretest method regarding SE Director General of Islamic Community Guidance No. P-003 and the consequences of online sirri marriage, religious lectures on online sirri marriage law in the perspective of Islamic law and positive law and its impact, post tests, discussions and legal consultations conducted online. So that the conclusion of this counseling is that the higher the level of public knowledge and understanding of the legal impact of online sirri marriage, the less desire and desire a person has to do it.
\end{abstract}

Keywords: online marriage sirri; Islamic law; Covid-19.

\title{
Pendahuluan
}

Pernikahan adalah syariat baginda nabi Muhammad SAW. Dalam keyakinan agama samawi pernikahan manusia telah dipraktekkan sejak zaman nabi Adam. Sedangkan dalam disiplin ilmu Ushul Fikih, hal ini dikenal dengan istilah "syar" "u man qablana", syariat nabi-nabi terdahulu yang masih berlaku sampai pada umat nabi Muhammad SAW. Setiap nabi membawa syariatnya masing-masing yang semuanya bersumber dari Allah SWT. Hanya saja, setiap syariat yang berlaku dan sesuai pada masa tertentu belum tentu selamanya sesuai dan berlaku pada masa setelahnya. Hukum selalu berubah mengikuti perubahan pola pikir dan kebutuhan manusia. Hukum boleh berubah tetapi tujuannya tetap sama yaitu kemaslahatan manusia. ${ }^{1}$

Selain dalam Islam, tradisi pernikahan dikenal dalam agama dan bangsa-bangsa di dunia ini. Praktiknya pun tergantung pada tradisi dan budaya masing-masing. Namun intinya adalah menjaga keberlangsungan reproduksi biologis dan melegalkan secara hukum aktivitas seks dan seksualitas manusia. Hanya dengan melalui lembaga perkawinan, kelahiran manusia baru akan mendapat perlindungan dan kepastian hukum. Lembaga perkawinan juga merupakan salah satu cara agama mengatur hubungan

\footnotetext{
${ }^{1}$ Abu Zahrah, Ushul al-Fiqh, (Beirut: Daar al-Fikr, tt), 305.
} 
seksualitas manusia. Tanpa pernikahan, seperti yang berlaku di masyarakat pra-Islam, perempuan tak ada harganya sama sekali. Perempuan dianggap sebagai komoditas yang layak diperjual belikan.

Islam juga memiliki aturan dan mekanisme tertentu sebagai syarat sah sebuah ikatan pernikahan. Syarat-syarat tersebut harus dipenuhi ketika akad. Pertama; wali: harus laki-laki, merdeka, sudah baligh (mukallaf), beragama Islam, adil, dan tidak cacat mental (tamm al-nazhar). ${ }^{2}$ Dimaksud dan termasuk dalam katagori "wali" disini adalah mereka yang memiliki kekuasaan atas anak dari garis keturunan bapak kandung. Dalam pernikahan, kekuasaan itu hanya dimiliki laki-laki, seperti orang tua laki-laki, kakek, paman (baik dari bapak/ibu), anak paman (sepupu), dan seterusnya. ${ }^{3}$ Seorang anak gadis perempuan, budak, orang gila, atau fasik tidak bisa menikahkan dirinya sendiri dan orang lain. Ia harus mendapat persetujuan orang tuanya (wali). Kedua, dihadiri dua orang saksi. Syarat-syarat saksi haruslah muslim. Di samping muslim, seorang saksi harus sehat mentalnya, sudah baligh, merdeka, adil, dan laki-laki. Perempuan tidak boleh menjadi saksi atau wali. Imam Malik tidak mensyaratkan adanya saksi dalam pernikahan. Kecuali untuk pernikahan diam-diam atau rahasia atau nikah sirri (tidak dihadiri banyak orang), maka tetap dibutuhkan saksi. Selain Imam Malik, ulama lain membolehkan pernikahan sirri asalakan dihadiri saksi. ${ }^{4}$ Ketiga, terdapatnya mempelai laki-laki dan perempuan itu sendiri. Keempat, ijab qobul (serah terima). Ijab qobul harus menggunakan kata-kata "al-inkah" (menikahkan) atau "al-tazwij" (menjodohkan) atau terjemahan dari keduanya.

Hampir semua agama, terutama agama samawi menganggap pernikahan sebagai sesuatu yang sakral. Sakralitas pernikahan terlihat dari syarat dan rukun yang harus dipenuhi ketika upacara pernikahan, seperti wali, saksi, mahar, ijab qobul. Hukum asal pernikahan adalah jawaz/ mubah (dibolehkan). Namun, pada perkembangan selanjutnya tergantung pada faktor-faktor yang mempengaruhi, nikah bisa wajib, sunah, makruh bahkan haram.

Saat ini, dunia sedang dilanda kekhawatiran dan bencana yang parah akibat situasi pandemi covid-19 yang sedang melanda umat di dunia, tradisi-tradisi kegamaan mencoba untuk beradabtasi dan mengubah tradisi. Termasuk halnya perkawinan. Baru-baru ini terbitnya edaran Menag tentang himbauan larangan resepsi pernikahan. Bahkan Dirjen Bimbingan Masyarakat Islam Kementerian Agama, Kamaruddin Amin mengatakan, pihaknya sementara waktu tak melayani pelaksanaan akad nikah bagi calon pengantin yang mendaftarkan diri setelah tanggal 1 April 2020. Hal ini merespon pandemi Covid-19 yang belakangan kian meluas. ${ }^{5}$

Grand Syaikh Al-Azhar pun menegaskan pada dunia dalam fanpage resmi Al-Azhar bahwa sudah menjadi kewajiban bagi semua orang untuk mengambil peran dalam mengatasi penyebaran covid-19 ini demi melindungi umat manusia dari bahaya. Di antaranya ialah Pertama, dalam kondisi yang sulit tersebut wajib bagi kita pihak negara, bangsa, individu, lembaga, hingga institusi untuk memikul bersama tanggung jawab ini dan mengambil perannya untuk melawan virus ini demi melindungi umat dari marabahaya. Kedua, kita wajib untuk mengenang dengan rasa bangga apresiatif dan menghargai dedikasi mereka yang berada dalam garda terdepan saat ini. Yaitu dokter, perawat, semua petugas tenaga medis. Karena mereka yang menerjang bahaya ini dengan segenap jiwa dan raga demi menolong umat manusia. Ketiga, usaha-usaha luar biasa yang dilakukan pihak terkait untuk menghalau virus, membangkitkan harapan bahwa kita mampu

\footnotetext{
${ }^{2}$ Muhammad al-Zuhri al-Ghamrawi, Anwar al-Masalik, Syarh „Umdah al-Salik wa „Uddah al-Nasik, (Beirut: Dar alKutub al-Islamiyyah, 2012), Cet.1, 215.

3 Taqiyuddin Abu Bakr ibn Muhammad al-Husayni, Kifayah al-Akhyar fi Halli Ghayah al-Ikhtishar (Vol. II),( Kediri: Ma'had al-Islami al-Salafy,tt), 51.

${ }^{4}$ Abu al-Mawahib Abdul Wahab ibn Ahmad ibn Ali-al-Anshari, al-Mizan al-Kubra, (Kediri: Ma'had al-Islami al-Salafy, $\mathrm{tt}), 33$.

${ }^{5}$ Fitria Chusna Farissa, "Wabah Covid-19, Kemenag Hanya Layani Akad Nikah yang Daftar Sebelum 1 April” dikuti dalam https://nasional.kompas.com/read/2020/04/03/14002231/wabah-covid-19-kemenag-hanya-layani-akad- nikah-yang-daftarsebelum-1-april. Hari Selasa, 7 April 2020 jam 16.00 WIB.
} 
terbebas dari Covid-19. Keempat, berdasarkan sejumlah kaidah fikih "Dar"u al-Mafasid Muqaddamun ,ala Jalbi al-Mashalih" (menolak kerusakan lebih didahukukan dibandingkan mengejar kemaslahatan), dan "Yuzaalu ad-Dhoror al-Akbar min ad-Dhoror al-Ashghor" (mudarat yang lebih besar hilang bersama dengan mudarat yang lebih kecil). Berangkat dari kaidah tersebut, Grand Syech menegaskan bahwa menuruti panduan kesehatan dan pemerintah yang dikeluarkan pihak otoritatif dan resmi, diantaranya adalah setiap orang terus menjaga kebersihan, melakukan social distancing, serta melaksanakan shalat lima waktu tepat waktu di rumah masing-masing tanpa berjamaah. ${ }^{6}$

Seiring dengan itu, meskipun Kementerian Agama juga ikut mengeluarkan aturan terbaru soal menikah selama wabah penyakit Covid-19, tetap saja begitu banyak calon pasangan pengantin yang merasa kecewa dengan keputusan ini. Contoh kasus calon pasangan pengantin Steffy Eks Cherrybelle dengan Temmy Ferdiawan yang akan melangsungkan pernikahan pada 18 April 2020 mendatang di Bali. Segala persiapan pernikahan sudah selesai 100 persen. $^{7}$ Ada juga Uti dan calon suaminya yang memilih untuk nikah siri dari pada menunda pernikahannya. ${ }^{8}$ Bahkan banyak juga yang tetap bersikeras melangsungkan resepsi pernikahan walau ternyata harus di cut oleh polisi.

Dari dampak Covid-19, banyak juga calon pengantin yang tetap ingin melangsungkan pernikahan via online. Nikah online adalah suatu bentuk pernikahan yang transaksi ijab qobulnya dilakukan melalui keadaan konektivitas atau kegiatan yang terhubung dengan suatu jaringan atau sistem internet, jadi antara mempelai lelaki dengan mempelai perempuan, wali dan saksi itu tidak saling bertemu dan berkumpul dalam satu tempat, yang ada dan ditampilkan hanya berbentuk visualisasi. ${ }^{9}$ Ironisnya, saat ini ada pula website yang memfasilitasi orang buat nikah siri. ${ }^{10}$ Padahal dalam situasi pandemi saat ini hakikatnya nikah sirri online belum bisa untuk diterapkan karena Kementerian Agama masih membuka pendaftaran walaupun pelaksanaanya ditunda sampai situasi membaik. Perkawinan sirri online belum termasuk katagori rukhsah, sebab rukhsah harus ditetapkan berdasarkan dali1. ${ }^{11}$

Dari berbagai penelusuran yang telah dilakukan, belum ada pengabdian yang mengkaji khusus tentang penyuluhan hukum nikah sirri online dalam tinjauan hukum Islam dan regulasi Menag tentang pencegahan Covid-19 di lingkungan KUA masyarakat TanjungPinang sekarang. Tentu hal ini merupakan hal yang baru sehingga tim pengabdi memberanikan diri untuk mengangkat masalah ini untuk dijadikan suatu pengabdian pada masyarakat.

Berdasarkan uraian diatas, tim pengabdi menganggap permasalahan ini sangat layak dikaji guna mencoba untuk memaparkan kepada masyarakat "Hukum Nikah Sirri Online dalam Tinjauan Hukum Islam dan Regulasi Menag tentang Pencegahan Covid-19 di Lingkungan KUA Masyarakat Tanjungpinang”.

\section{Metode}

6 Muhammad Masrur, "Pesan dan Doa Grand Syaikh Al-Azhar terkait Virus Corona" dikutip dalam https://bincangsyariah.com/zikir-dan-doa/pesan-dan-doa-grand-syaikh-al-azhar-terkait-virus-corona/. Hari selasa, 7 April 2020, jam 18.00 WIB.

7 Sapto Purnomo, "Steffy eks Cherrybelle Batal Nikah karena Corona Covid-19 meski Persiapan Sudah 100 Persen" dikutip dalam https://www.liputan6.com/showbiz/read/4211362/steffy-eks-cherrybelle-batal-nikah- karena-corona-covid-19-meskipersiapan-sudah-100-persen. Hari selasa, 7 April 2020, jam 18.00 WIB.

${ }^{8}$ Wawancara dengan Uti calon pasangan pengantin di Batam. Hari senin, 6 April 2020, jam 18.00.

${ }^{9}$ Miftah Farid, "Nikah Online dalam Perspektif Hukum Islam”, Jurnal Yurisprudentie, Vol. 5, No. 1 Juni $2018,178$.

10 Ardi Mandiri, "Khofifah: Perempuan Jangan Mau Nikah Siri Online", dikutip dalam https://www.suara.com/lifestyle/2015/03/23/044000/khofifah-perempuan-jangan-mau-nikah-siri-online, Hari selasa, 7 April 2020, jam 18.00 .

${ }_{11}$ Ahmad Jalili, “Konsep Rukhsah dan Implementasinya”, Perada: Jurnal Studi Islam Kawasan Melayu, Vol.1, No. 2, Desember 2018, hal, 114. 
Metode yang digunakan dalam pengabdian masyarakat di perumahan mutiara bintan ini menggunakan metode penyuluhan kepada masyarakat. Penyuluhan ini disesuaikan dengan kondisi dan situasi dalam keadaan pandemi Covid-19 dimana dilarang untuk melakukan perkumpulan secara langsung. Oleh sebab itu, penyuluhan pada pengabdian masyarakat ini menggunakan sistem online dengan memanfaatkan media grup Watsapp masyarakat.

Target sasaran kegiatan ini adalah pada jama'ah mushalla Nurul Mubin Jl. Adi Sucipto Batu 10 Perumahan Mutiara Bintan RT.08/ RW 01, Kelurahan Pinang Kencana, Kecamatan Tanjung Pinang Timur, Kota Tanjungpinang. Hal tersebut dikarenakan Jama'ah musholla Nurul Mubin terdiri dari keluarga-keluarga yang aktif menghidupkan musholla tersebut dalam kesehariannya. Tidak hanya dalam pelaksanaan kegiatan formal, namun juga dalam berbagai kegiatan kemasyarakatan lainnya juga bertumpa pada musholla ini. Kegiatan-kegiatan tersebut seperti pendidikan, musyawarah warga, kajian-kajian keagamaan dan lain sebagainya. Artinya, kegiatan-kegiatan masyarakat bertumpu pada musholla ini.

Pemilihan lokasi ini adalah dikarenakan pada umumnya, masyarakat Tanjungpinang secara mayoritas telah melek tekhnologi online. Dari mulai usia muda hingga dewasa, sudah mampu mengoperasikan tekhnologi online. Sehingga dengan terpahaminya teknologi online tersebut, akan memungkinkan untuk pelaksanaan pernikahan secara online di tengah kondisi pandemi Corona seperti saat ini. Hal tersebut senada dengan data awal yang telah tim dapatkan, bahwa mayoritas masyarakat di Kelurahan pinang kencana tersebut secara faktor ekonomi dapat dikatakan mapan. Dari segi pekerjaan, mayoritas masyarakat disana adalah PNS baik sipil maupun militer, BUMN, wiraswasta, nelayan dan sebagainya. Artinya, mayoritas masyarakat disana sudah memiliki perkerjaan yang mapan dan sangat sedikit yang pengangguran. Dari data awal yang didapatkan, bahwa mayoritas masyarakat di kelurahan pinang kencana adalah beragama Islam. Umumnya masyarakat disana taat beribadah di masjid maupun musholla sebagai sarana ibadah wajibnya, yang salah satunya adalah musholla Nurul Iman. Di Musholla Nurul Iman inilah, selain tempat beribadah masyarakat, juga dilaksanakan sarana pendidikan-pendidikan al-Quran bagi anak-anak, tempat berkumpulnya para pemuda-pemuda dalam mendengarkan kajian-kajian keagamaan.

Namun, dari data awal yang didapatkan, ada juga beberapa orang dari jamaah musholla tersebut yang melaksanakan perkawinan sirri. Dengan demikian, menjadi tepat kiranya memilih jamaah musholla Nurul Iman kelurahan Tanjungpinang Timur ini dalam pelaksanaan pengabdian masyarakat. Pertimbangan tersebut dijatuhkan berdasarkan pertimbangan tingkat perekonomian masyarakat, meleknya penggunaan tekhnologi, aktifnya masyarakat dalam meramaikan tempat ibadah (sebelum pandemi corona), ramainya kalangan muda yang akan melangsungkan pernikahan, dan ada beberapa jamaah yang telah melaksanakan pernikahan secara sirri. Pengabdian masyarakat ini bertujuan memberikan pemahaman kepada masyarakat yang rinci terkait Hukum pernikahan sirri secara online baik dari segi Hukum Islam maupun positifnya. Yang mana, pada masa saat ini sudah mulai maraknya pernikahan sirri secara online di berbagai kalangan. Sehingga, merasa perlu kiranya untuk memberikan informasi yang mendalam kepada sebanyak-banyaknya masyarakat dan dalam rangka pembinaan untuk membendung perkawinan sirri secara online. Dan dalam pengabdian ini pula disampaikan terkait pelaksanaan perkawinan dalam pencegahan wabah Covid 19 sebagaimana edaran Kementerian Agama.

Tim pengabdi berpartisipasi secara langsung dalam pemecahan permasalahan terkait isu perkawinan sirri online yang semakin merebak di tengah masyarakat. Sehingga hal tersebut dapat berfungsi dalam optimalisasi fungsi-fungsi keluarga dikarenakan sudah terpahaminya dampak-dampak negatif dalam perkawinan sirri secara online yang salah satunya adalah dapat terjadinya ketidakpastian hukum.

Kegiatan ini juga terlaksana berkat kerjasama yang baik dengan para tokoh masyarakat yang berada di perumahan mutiara bintan tersebut. Berkat para tokoh masyarakat yang bersedia mempersilahkan 
musholla nurul mubin sebagai tempat bagi tim pengabdian masyarakat untuk membuat sebuah video penyuluhan hukum. Sehingga, proses pembuatan video penyuluhan hukum tersebut dapat berjalan sebagaimana mestinya. Tidak sampai disitu, para tokoh masyarakat tersebut juga mempersilahkan tim pengabdian masyarakat untuk bergabung kedalam grup watsapp masyarakat Perumahan Mutiara Bintan yang menjadi jamaah dari mushalla nurul mubin. Dengan demikian, kegiatan dari mulai penyiapan video penyuluhan hukum, share video di grup watsapp masyarakat, hingga dialog interaktif antara tim pengabdian masyarakat dengan masyarakat setempat dapat berjalan dengan baik.

Tahapan awal yang dilakukan tim penyusun adalah melakukan pendataan secara lebih mendalam kepada pemuda dan masyarakat setempat yang notabenenya adalah jamaah musholla Nurul Iman. Pendataan dilaksanakan dengan melakukan koordinasi kepada pengurus musholla maupun tokoh masyarakat setempat seperti RT dan RW. Pengumpulan data ini bertujuan untuk mendapatkan informasi yang mendalam terkait jamaah masjid Nurul Iman agar tim pengabdi dapat mengidentifikasi permasalahan mitra pengabdian. Setelah smua data terkumpul, tim pengabdi mempersiapkan bahan penyuluhan terkait perkawinan sirri secara online dan dampak negatifnya yang berupa file video. Setelah data-data penyuluhan tersebut selesai, maka data-data tersebut segera disampaikan kepada masyarakat melewati pengurus musholla dan tokoh masyarakat tingkat RT dan RW.

Dengan adanya penyuluhan tersebut, diharapkan dapat meningkatkan pemahaman masyarakat sehingga dapat membendung terjadinya perkawinan sirri secara online dan agar masyarakat luas dapat memahami langkah dan prosedur perkawinan dalam pencegahan covid 19 di KUA. Tercapainya keberhasilan dalam pelaksanaan pengabdian ini akan mendatangkan manfaat bagi masyarakat akan terpahamkannya dampak negatif dari perkawinan sirri secara online. Disamping itu juga masyarakat akan tahu bagaimana langkah-langkah perkawinan dalam situasi dan kondisi saat ini.

Dari pemaparan diatas tersebut, model pada pengabdian masyarakat ini menggunakan metode Posdaya (pos pemberdayaan keluarga). Metode ini merupakan wadah antar keluarga yang kondisi sosial ekonomi dan budayanya bervariasi, mulai dari keluarga yang lemah (fakir miskin) sampai pada keluarga dengan posisi tinggi (kaya raya). Posdaya sebagai forum silaturahmi, komunikasi, dan advokasi antar keluarga mempunyai peran fungsi yang sangat penting dalam membangun keluarga dan masyarakat untuk mendapatkan kesejahteraan lahir bathin. Posdaya sebagai salah satu model pemberdayaan keluarga dan masyarakat mengutamakan partisipasi dalam memecahkan masalah yang ada di masyarakat sesuai dengan potensi dan kebutuhannya. Posdaya sebagai wadah silaturahmi antar keluarga dan antar anggota keluarga juga berperan untuk mendorong penyegaran dan optimalisasi fungsi-fungsi keluarga tersebut. Dalam hal tersebut, tim pengabdi mengembangkan sebuah posdaya khususnya pada jama'ah mushalla Nurul Mubin Jl. Adi Sucipto Batu 10 Perumahan Mutiara Bintan RT.08/ RW 01, Kelurahan Pinang Kencana, Kecamatan Tanjung Pinang Timur, Kota Tanjungpinang. Posdaya yang dibentuk ini sebuah posdaya yang berbasis musholla.

\section{Hasil dan Pembahasan}

Pengabdian ini dilakukan untuk memberikan penyuluhan hukum kepada masyarakat terkait larangan pelaksanaan perkawinan sirri secara online baik dari perspektif hukum Islam maupun hukum positif dan memberikan pemahaman yang jelas terkait pencegahan penyebaran Covid-19 pada layanan KUA sebagaimana yang terdapat dalam surat edaran Kementerian Agama No. P-003/DJ.III/Hk.00.7/03/2020 tentang pelaksanaan protokol penanganan Covid 19 pada area publik di lingkungan Direktorat Jenderal Bimbingan Masyarakat Islam. Sasaran kegiatan pengabdian ini adalah di kota Tanjungpinang, khususnya pada jama'ah mushalla Nurul Mubin Jl. Adi Sucipto Batu 10 Perumahan Mutiara Bintan RT.08/ RW 01, 
Kelurahan Pinang Kencana, Kecamatan Tanjung Pinang Timur, Kota Tanjungpinang. Pemilihan lokasi ini adalah dikarenakan pada umumnya, masyarakat Tanjungpinang secara mayoritas telah melek tekhnologi online. Dari mulai usia muda hingga dewasa, sudah mampu mengoperasikan teknologi online. Sehingga dengan terpahaminya teknologi online tersebut, akan memungkinkan untuk pelaksanaan pernikahan secara online di tengah kondisi pandemi Covid-19 seperti saat ini. Hal tersebut senada dengan data awal yang telah tim dapatkan, bahwa mayoritas masyarakat di kelurahan Pinang Kencana tersebut secara faktor ekonomi dapat dikatakan berada diatas rata-rata. ${ }^{12}$ Dari segi pekerjaan, mayoritas masyarakat disana adalah PNS baik sipil maupun militer, BUMN, wiraswasta, nelayan dan sebagainya. Artinya, mayoritas masyarakat disana sudah memiliki perkerjaan yang mapan dan sangat sedikit yang pengangguran. Dari data awal yang didapatkan, bahwa mayoritas masyarakat di kelurahan Pinang Kencana adalah beragama Islam. Umumnya masyarakat disana taat beribadah di masjid maupun musholla sebagai sarana ibadah wajibnya, yang salah satunya adalah musholla Nurul Iman. Di Musholla Nurul Iman inilah, selain tempat beribadah masyarakat, juga dilaksanakan sarana pendidikan-pendidikan al-Quran bagi anak-anak, tempat berkumpulnya para pemuda-pemuda dalam mendengarkan kajian-kajian keagamaan.

Namun, dari data awal yang didapatkan, ada juga beberapa orang dari jamaah musholla tersebut yang melaksanakan perkawinan sirri. Dengan demikian, menjadi tepat kiranya memilih jamaah musholla Nurul Iman kelurahan Tanjungpinang timur ini dalam pelaksanaan pengabdian masyarakat. Pertimbangan tersebut dijatuhkan berdasarkan pertimbangan tingkat perekonomian masyarakat, meleknya penggunaan teknologi, aktifnya masyarakat dalam meramaikan tempat ibadah (sebelum pandemi Covid-19), ramainya kalangan muda yang akan melangsungkan pernikahan, dan ada beberapa jamaah yang telah melaksanakan pernikahan secara sirri. Pengabdian masyarakat ini bertujuan memberikan pemahaman kepada masyarakat yang rinci terkait hukum pernikahan sirri secara online baik dari segi hukum Islam maupun positifnya. Yang mana, pada masa saat ini sudah mulai maraknya pernikahan sirri secara online di berbagai kalangan. Sehingga, merasa perlu kiranya untuk memberikan informasi yang mendalam kepada sebanyak-banyaknya masyarakat dan dalam rangka pembinaan untuk membendung perkawinan sirri secara online. Dan dalam pengabdian ini pula disampaikan terkait pelaksanaan perkawinan dalam pencegahan wabah Covid- 19 sebagaimana edaran Kementerian Agama.

Rencana dan tahapan awal yang dilakukan tim pengabdi adalah melakukan pendataan secara lebih mendalam kepada pemuda dan masyarakat setempat yang notabenenya adalah jamaah musholla Nurul Iman. Pendataan dilaksanakan dengan melakukan koordinasi kepada pengurus musholla maupun tokoh masyarakat setempat seperti RT dan RW. Pengumpulan data ini bertujuan untuk mendapatkan informasi yang mendalam terkait jamaah masjid Nurul Mubin agar tim pengabdi dapat mengidentifikasi permasalahan mitra pengabdian. Setelah semua data terkumpul, tim pengabdi mempersiapkan bahan penyuluhan terkait perkawinan sirri secara online dan dampak negatifnya yang berupa ceramah keagamaan dalam bentuk video. Selain itu tim pengabdi juga akan menggunakan metode pre test, post test, diskusi dan konsultasi hukum yang dilakukan melalui via daring.

Dengan adanya penyuluhan tersebut, diharapkan dapat membendung terjadinya perkawinan sirri secara online dan agar masyarakat luas dapat memahami langkah dan prosedur perkawinan dalam pencegahan Covid-19 di KUA. Tercapainya keberhasilan dalam pelaksanaan pengabdian ini akan mendatangkan manfaat bagi masyarakat akan terpahamkannya dampak negatif dari perkawinan sirri secara online. Disamping itu juga masyarakat akan tahu bagaimana langkah-langkah perkawinan dalam situasi pandemi Covid-19 saat ini. Lebih dari itu, tim juga akan memberikan penyuluhan tentang begitu besarnya peran keluarga dalam mendukung regulasi Menag terhadap calon pengantin. Karena secara psikis, kondisi ini

${ }^{12}$ M. Arbisora Angkat, "Urgensi Kalender Hijriyah Sebagai Haul Zakat Maal Di Baznas Provinsi Kepulauan Riau", TERAJU : Jurnal Syariah dan Hukum, Vol. 2, No. 1, 2020, h. 23 
sangat berdampak kepada psikologi catin. Karena mereka yang tengah berbahagia menyambut hari bersejarah dalam hidupnya meski ditunda karena pandemi ini. Belum lagi, catin yang mesti mengalami kerugian materi maupun non materi. Semisal, undangan pernikahan yang sudah disebar, catering yang sudah di DP, dan lain-lain.

Adapun rencana kegiatan akan dilaksanakan selama 3 bulan terhitung mulai bulan April s/d Juni 2020. Dengan jadwal kegiatan sebagai berikut:

Tabel 1

Tahapan Pelaksanaan Kegiatan

\begin{tabular}{|c|c|c|c|c|c|c|c|c|c|c|c|}
\hline \multirow[t]{3}{*}{ No } & \multirow{3}{*}{$\begin{array}{l}\text { Tahapan-Tahapan } \\
\text { Pelaksanaan }\end{array}$} & \multicolumn{10}{|c|}{ Bulan } \\
\hline & & \multicolumn{4}{|c|}{ April } & \multicolumn{4}{|c|}{ Mei } & \multicolumn{2}{|l|}{ Juni } \\
\hline & & M.1 & M.2 & M.3 & M.4 & M.1 & M.2 & M.3 & M.4 & M.1 & M.2 \\
\hline 1 & $\begin{array}{ll}\text { Persiapan } & \text { dan } \\
\text { pengumpulan data } & \end{array}$ & $\sqrt{ }$ & $\sqrt{ }$ & $\sqrt{ }$ & & & & & & & \\
\hline 2 & Pelaksanaan sosialisasi & & & & $\sqrt{ }$ & $\sqrt{ }$ & $\sqrt{ }$ & & & & \\
\hline 3 & $\begin{array}{ll}\text { Penyusunan } & \text { Laporan } \\
\text { progres } & \end{array}$ & & & & & & & $\sqrt{ }$ & $\sqrt{ }$ & & \\
\hline 4 & $\begin{array}{lr}\text { Pengadaan } & \text { dan } \\
\text { Penyerahan } & \text { Laporan } \\
\text { serta penerbitan jurnal }\end{array}$ & & & & & & & & & $\sqrt{ }$ & $\sqrt{ }$ \\
\hline
\end{tabular}

Adapun uraian dari kolom diatas adalah sebagai berikut:

\section{Persiapan}

Tim Pengabdi melakukan rapat dan melukakan kegiatan surat menyurat yang ditujukan pada mushalla Nurul Mubin Jl. Adi Sucipto Batu 10 Perumahan Mutiara Bintan RT.08/ RW 01, Kelurahan Pinang Kencana, Kecamatan Tanjung Pinang Timur, Kota Tanjungpinang. Pada tahap ini juga tim pengabdi melakukan penjajakan pada lokasi serta mempersiapkan bahan/materi yang akan disajikan dalam penyuluhan/ceramah. Kegiatan ini dilakukan selama 3 minggu, yaitu : Minggu pertama hingga minggu ketiga bulan April.

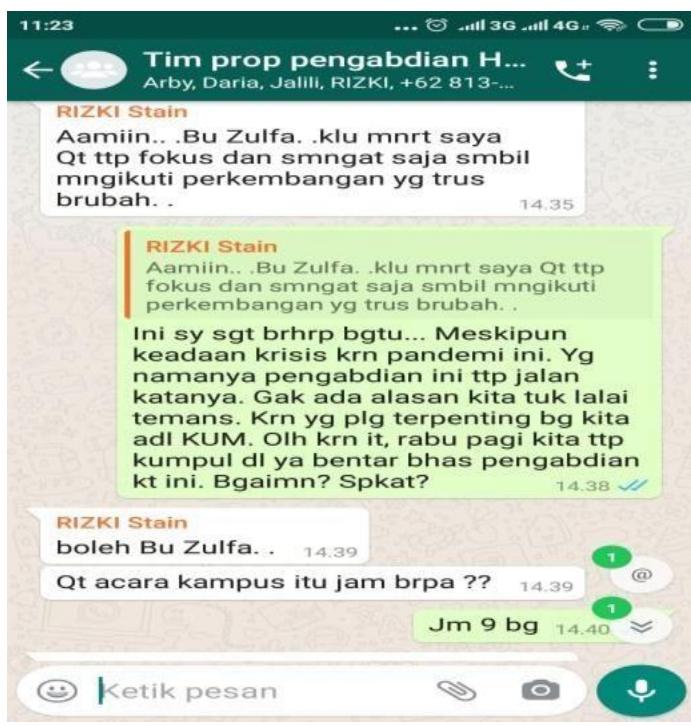

Gambar 1. Dosen Pengabdi mengadakan rapat via daring 


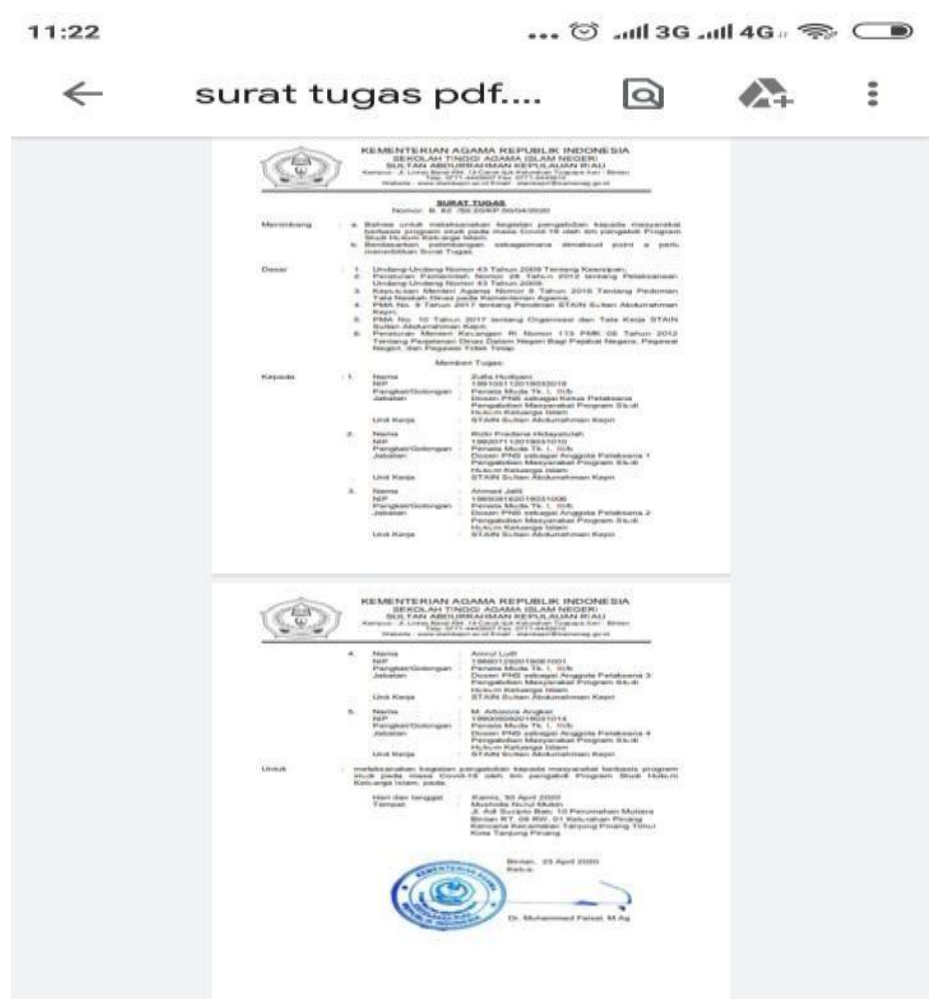

Gambar 2. Dosen Pengabdi menyiapkan surat menyurat
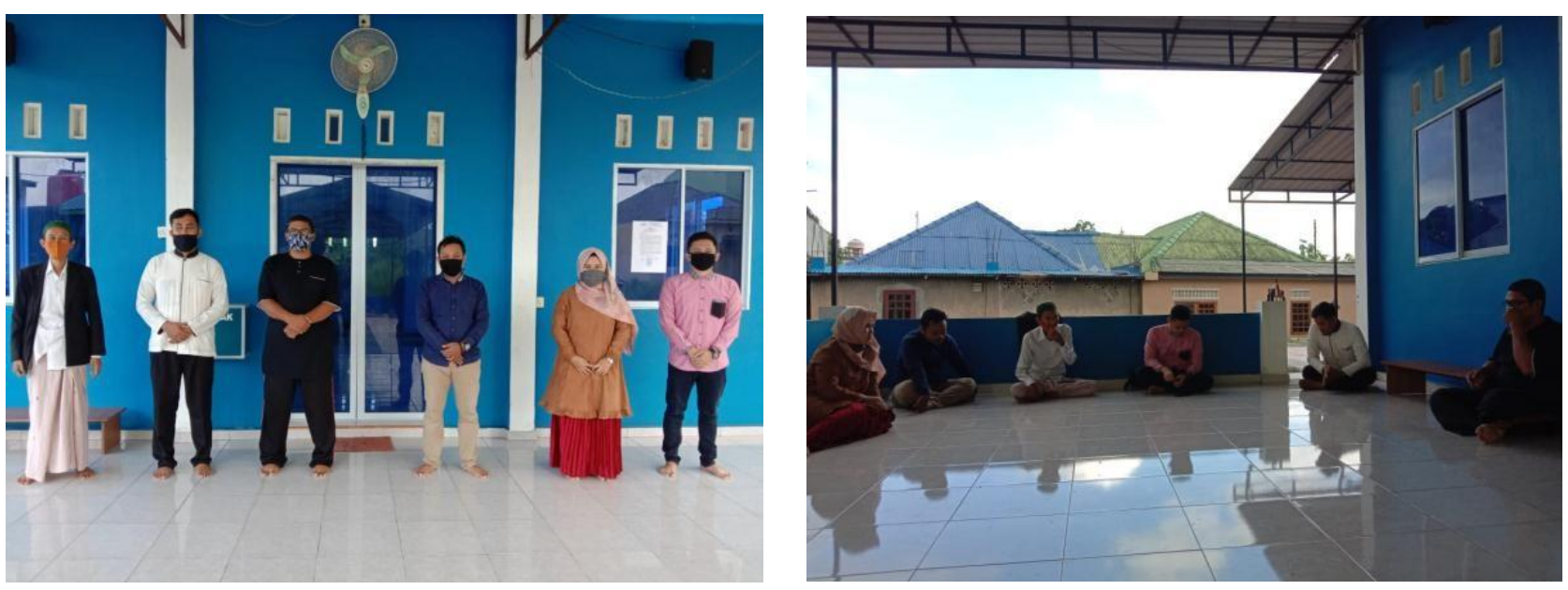

Gambar 3. Dosen Pengabdi melakukan survey lapangan dan koordinasi dengan ketua RT

\section{Pelaksanaan}

Tim Pengabdi Prodi Hukum Keluarga Islam melakukan kegiatan pretest tentang SE Dirjen Bimas Islam No. P-003 dan akibat dari perkawinan sirri online, ceramah keagamaan mengenai hukum perkawinan sirri online dalam perspektif hukum Islam dan hukum positif serta dampaknya, post test, diskusi dan konsultasi hukum yang dilakukan melalui via daring. Kegiatan ini dilaksanakan selama 3 minggu, yaitu: Minggu keempat dibulan April hingga Minggu kedua di bulan Mei. 


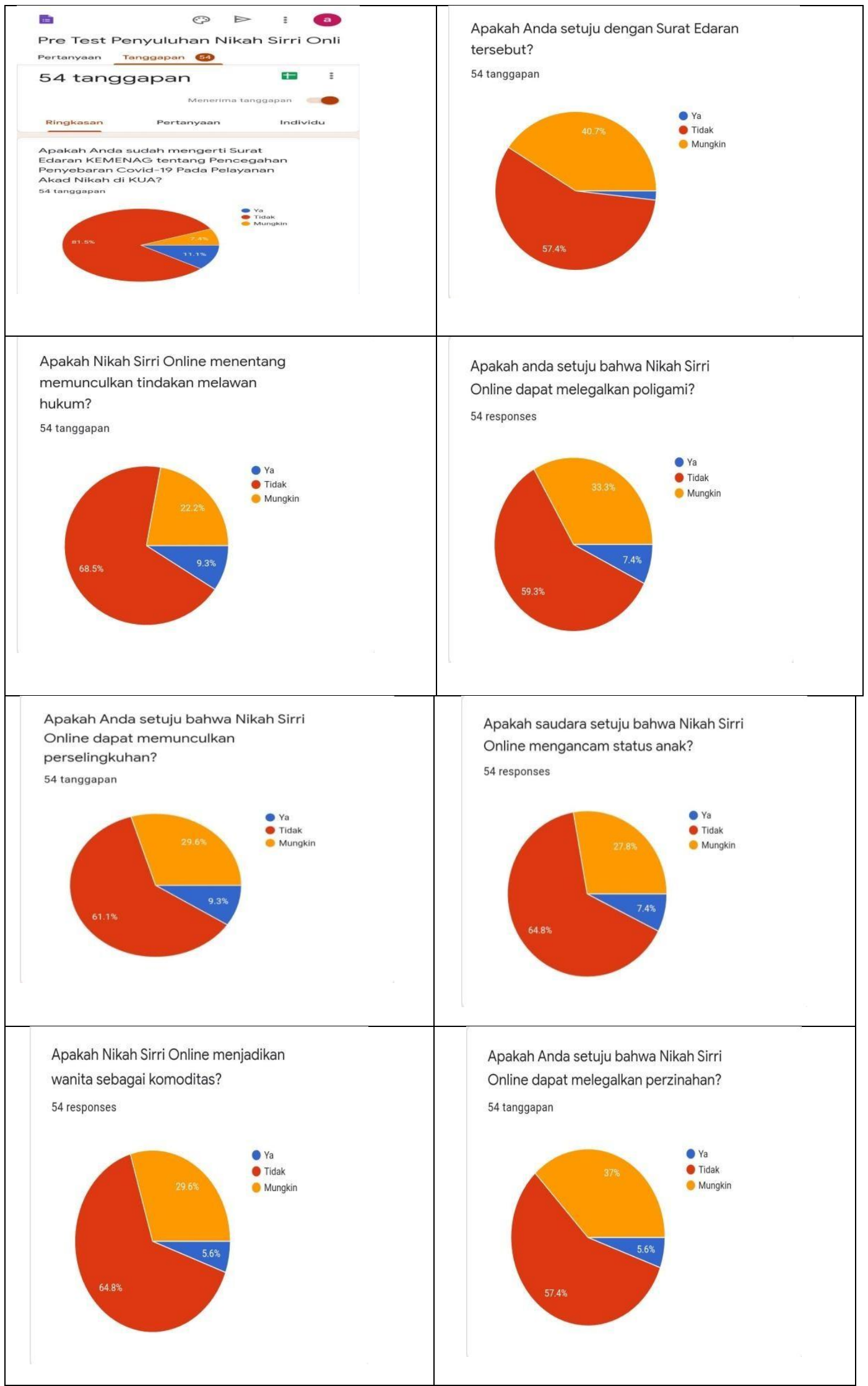

Gambar 4. pretest penyuluhan hukum nikah sirri online terhadap warga jamaah Nurul Mubin 
Melakukan Pre-test kepada masyarakat perumahan mutiara bintan dengan menyebarkan angket secara online berisi 10 pertanyaan yang menjadi indikator dari pemahaman masyarakat perumahan mutiara bintan terkait dampak negatif dari pernikahan sirri online dan terkait aturan regulasi dari kementerian agama tentang pencegahan Covid-19 di lingkungan KUA. 10 Pertanyaan tersebut adalah:

a. Apakah saudara sudah mengetahui surat edaran kemenag tentang pencegahan penyebaran Covid19 pada pelayanan akad nikah di KUA?

b. Apakah saudara setuju dengan surat edaran tersebut?

c. Menurut saudara, apakah nikah sirri online sudah sesuai dengan syariat Islam?

d. Menurut saudara, apakah nikah sirri online menentang memunculkan tindakan melawan hukum?

e. Apakah saudara setuju bahwa nikah sirri online dapat memunculkan perselingkuhan?

f. Apakah saudara setuju bahwa nikah sirri online mengancam status anak?

g. Apakah nikah sirri online melanggar undang-undang tentang pencatatan pernikahan?

h. Apakah saudara setuju bahwa nikah sirri online dapat melegalkan perzinahan?

i. Apakah saudara setuju bahwa nikah sirri online dapat melegalkan poligami?

j. Menurut saudara, apakah nikah sirri online menjadikan wanita sebagai komoditas?

Tujuan dari melakukan pre-test dengan menyebarkan angket secara online tersebut adalah untuk mengukur tingkat pemahaman masyarakat terhadap permasalahan nikah sirri online dan surat edaran kemenag tentang pencegahan penyebaran Covid-19 pada pelayanan akad nikah di lingkungan KUA. Dan juga bertujuan untuk sebagai masukan bagi tim pengabdian masyarakat dalam menyusun materi penyuluhan hukum agar sesuai dengan fokus materi yang belum dipahami masyarakat sehingga penyuluhan lebih efektif.

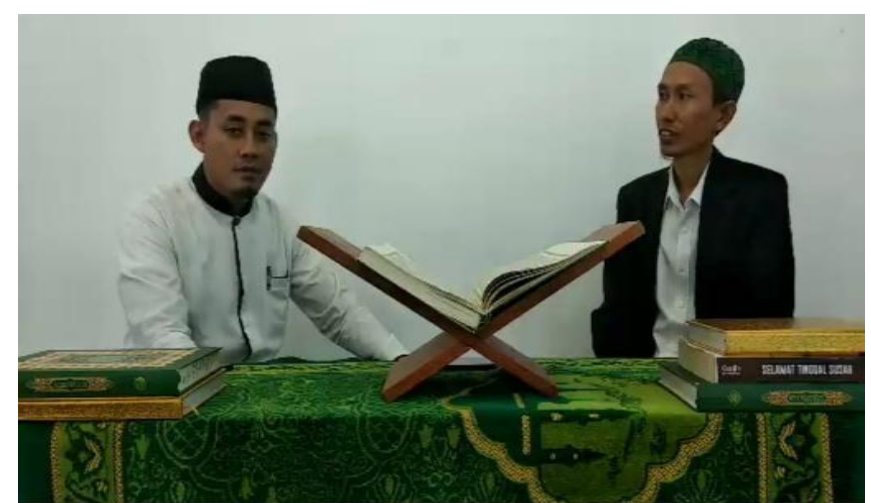

[0] @stainkepri f Stain Kepri http://stainkepri.ac.id
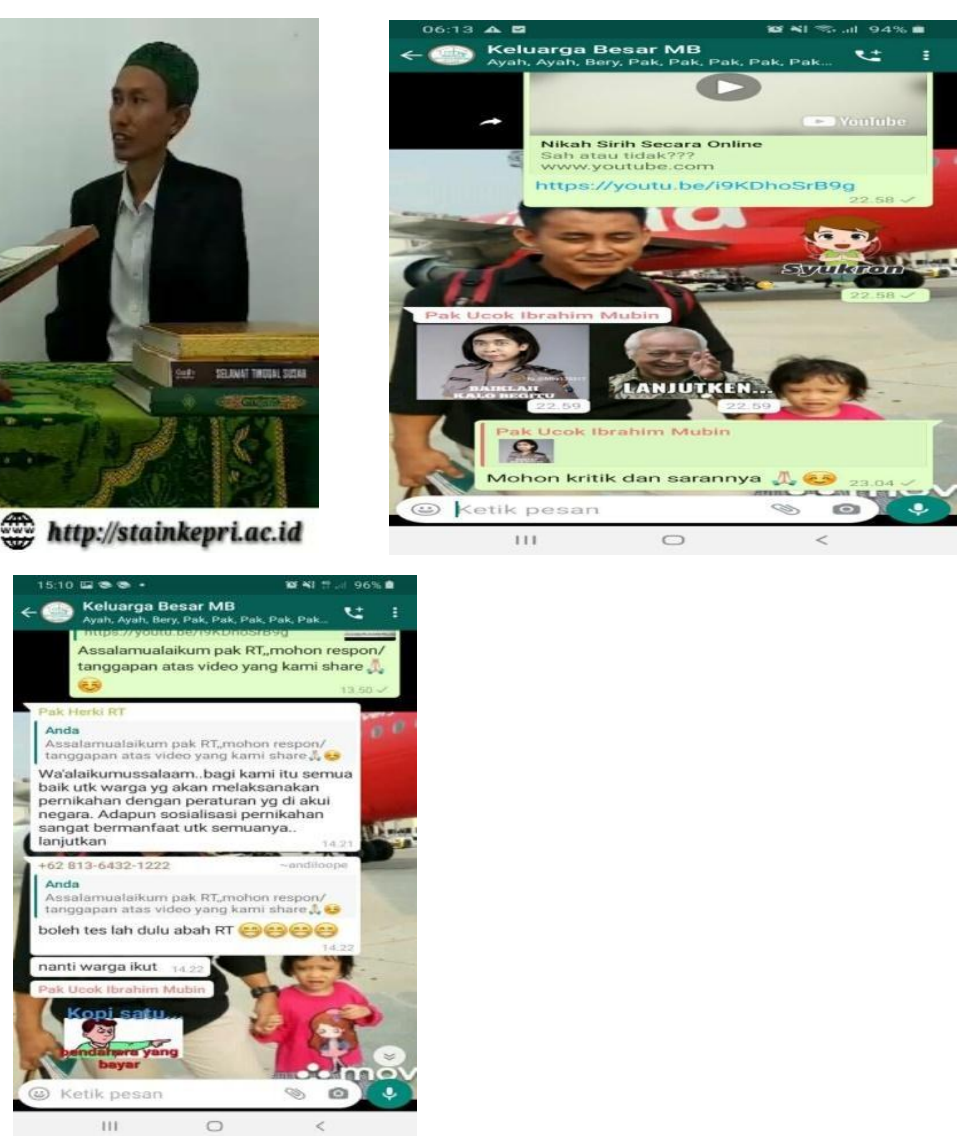

Gambar 5. Memberikan Penyuluhan kepada masyarakat berupa video kajian keagamaan 
Membuat video penyuluhan hukum dengan tema terkait oleh Kyai Ustad Jalili dan Amrul Lutfi sebagai moderator yang dilaksanakan pada musholla nurul mubin yang terletak pada perumahan mutiara bintan. Pembuatan video ini bertujuan sebagai penyuluhan hukum secara online tentang tema terkait yang nantinya akan dishare di grup watsapp masyarakat mutiara bintan. Dalam teknis video tersebut berisi paparan materi penyuluhan yang disampaikan tim pengabdian.

Pengabdian yang akan dilakukan adalah terkait perkawinan sirri online. Perkawinan adalah persoalan madaniyyah bukan diniyyah, persoalan muamalah bukan ibadah. Hal ini dibukti kan dengan: 1. Persoalan hukum perkawinan yang dinamis dan tidak mengenal hukum tunggal; 2. Perkawinan sangat erat kaitannya dengan kebijakan pemerintah disuatu negara; dan 3. Perkawinan dalah bentuk negosiasi dan interaksi egalitar antara anak dan orangtua serta antara lelaki dan perempuan dalam menentukan masa depan rumah tangga yang memenuhi dan mencapai tujuan mulia sebuah perkawinan. ${ }^{13}$ Prof. Dr. Wahbah Zuhaili menyatakan bahwa hukum perkawinan menurut para ahli fikih sangat tergantung pada situasi dan kondisi seseorang. ${ }^{14}$ Dari sekian banyak hukum perkawinan yang tidak tunggal, kita melihat secara lebih jelas bahwa perkawinan sirri online termasuk kedalam jenis hukum yang ada. Katagori hukum ditentukan pada illah (sebab) yang terdapat pada persoalan perkawinan sirri online. Pernikahan semacam ini ternyata membawa mudharat menimbulkan mafsadah, sudah barang tentu hukumnya haram. Sebab, adanya hukum disebabkan adanya illah. Mudhorot dan mafsadat itulah sebagai kausa bagi dimasukkannya nikah sirri online kedalam katagori haram. Perkawinan sirri online sudah tentu tidak tercatat di KUA. Padahal pencatatan perkawinan ialah salah satu bentuk pembaharuan hukum Islam yang mana kandungan didalamnya sangat besar sekali. ${ }^{15}$ Yaitu sejalan dengan ketentuan syara' mewujudkan kemashlahatan dan mencegah kemudhorotan.

Kemudian, perkawinan adalah salah satu persoalan dalam Islam yang sejak lama berkolerasi atau berelasi dengan negara, kepemerintahan. Perkawinan diatur oleh sebuah pemerintah. Secara historis, negaranegara Islam mengatur perkawinan sebagai bagian dari kebijakan politik kependudukan ketika Islam telah menyebar ke wilayah-wilayah lain dan berhubungan dengan budaya hukum warisan Yunani dan Romawi.

Dalam konteks nikah online, hal ini bersebrangan oleh kesepakatan para ulama yang ditegaskan Wahbah Zuhaili dalam bukunya al-Figh wa Adillatuhu bahwa dalam shigat akad (ijab dan qabul) disyaratkan empat hal:1. Kesesuaian dan ketepatan kalimat ijab dengan qabul, 2. Orang yang mengucapkan kalimat ijab tidak boleh menarik kembali ucapannya, 3. Diselesaikan pada waktu akad, 4. Dilakukan dalam satu majelis (ittihād al-majlis). ${ }^{16} \mathrm{Hal}$ ini yang membedakan nikah online dan nikah biasa adalah pada esensi ittihäd al- majlis yang erat kaitannya dengan tempat (makan) pada implementasi atau pelaksanaan akadnya, meskipun selebihnya semuanya sama.

Selain berupa pemaparan tentang tema terkait, dalam video tersebut juga ada dialog interaktif seputar pernikahan sirri online dalam pandangan hukum positif dan hukum Islam. Sehingga video tersebut tidak berjalan secara monoton. Share video ke dalam grup watsapp masyarakat perumahan mutiara bintan. Share video ini bertujuan agar materi penyuluhan yang sudah disiapkan, dapat tersajikan kepada masyarakat secara online. Saat share video ke dalam grup watsapp ini juga dibuka sesi tanya jawab antara tim pengabdian masyarakat dengan masyarakat perumahan mutiara bintan. Dengan adanya sesi tanya jawab ini adalah sebagai bentuk dialog interaktif yang bertujuan untuk memberikan pemahaman kepada masyarakat secara langsung.

${ }^{13}$ Mukti Ali, Roland Gunawan, dkk, Fikih Kawin Anak: Membaca Ulang Teks Keagamaan Perkawinan Usia Anak-anak, (Jakarta: Rumah Kitab, 2015), 25.

${ }^{14}$ Wahbah Zuhaili, al-Fiqh al-Islamy waAdillatuhu, 46

${ }^{15}$ Zulfa Hudiyani, "Kontribus Mashlahah At-Thufi dalam Pembaharuan Hukum Islam di Era Kontemporer",Teraju: Jurnal Syariah dan Hukum, Vol. 01, No. 2, September 2019, hal 57

${ }^{16}$ Wahbah Zuhaili, al-Fiqh al-Islamy waAdillatuhu, 98 


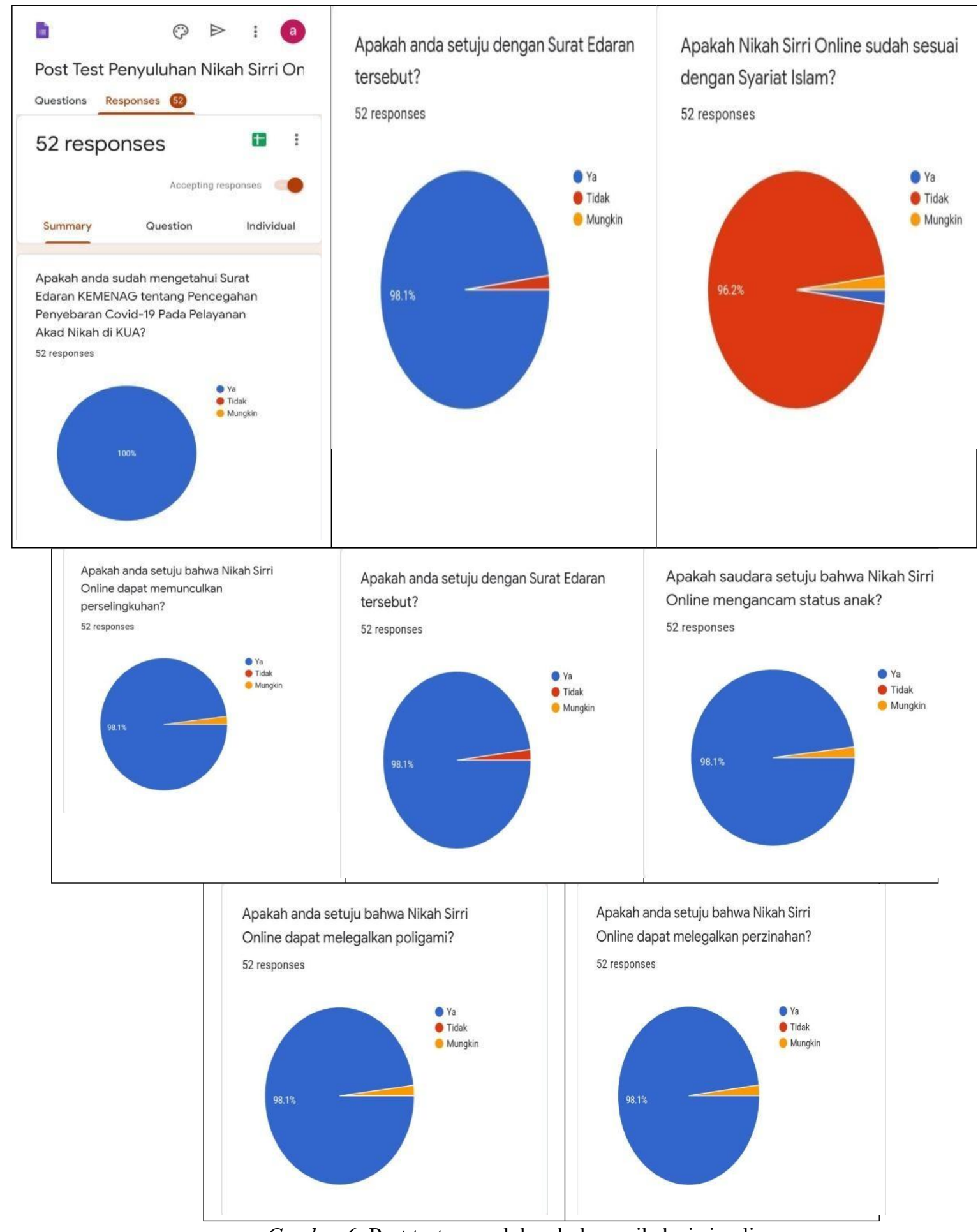

Gambar 6. Post test penyuluhan hukum nikah sirri online

Melakukan evaluasi dengan melakukan post-test yang dilaksanakan dengan menyebarkan angket. Pelaksanaan post-test ini bertujuan untuk melihat tingkat pemahaman masyarakat setelah dilaksanakannya penyuluhan dan dialog interaktif secara online.

\section{Penyusunan Laporan}

Tim Pengabdi menyusun laporan Selama 2 Minggu, yaitu: Minggu ketiga dan Keempat bulan Mei. 


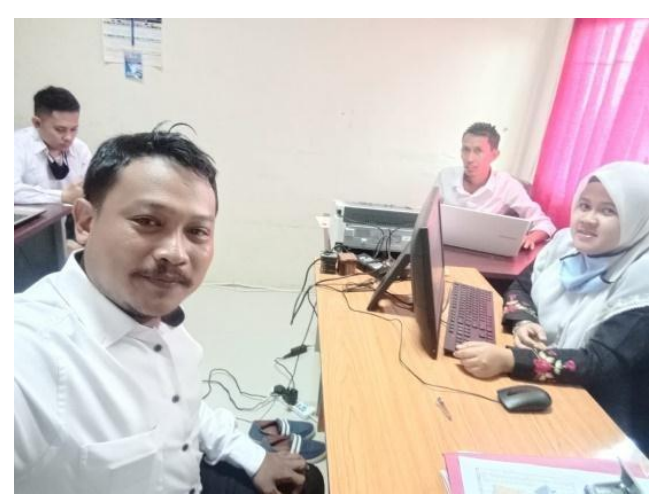

Gambar 7. Dosen Pengabdi menyusun laporan hasil akhir

\section{Pengadaan dan Penyerahan Laporan}

Tim Pengabdi mencetak laporan, menyerahkan dan Menyampaikan Laporan. Kegiatan ini dilakukan selama 2 Minggu, yaitu: Minggu kesatu dan kedua bulan Juni.

\section{Kesimpulan}

Pelaksanaan kegiatan pengabdian kepada masyarakat oleh Pusat Penelitian dan Pengabdian Masyarakat (PPPM) Sekolah Tinggi Agama Islam Sultan Abdurrahman Kepulauan Riau yang dilakukan oleh dosen-dosen Program Studi Hukum Keluarga Islam yang mengusung tema "Berbasis Program Studi pada Kondisi Covid-19" berjalan dengan lancar dan mendapat sambutan baik dari tempat pelaksanaan kegiatan penyuluhan yakni khususnya pada jama'ah mushalla Nurul Mubin Jl. Adi Sucipto Batu 10 Perumahan Mutiara Bintan RT.08/ RW 01, Kelurahan Pinang Kencana, Kecamatan Tanjung Pinang Timur, Kota Tanjungpinang.

Dengan dilaksanakannya Pengabdian Kepada Masyarakat ini diharapkan dapat memberikan pemahaman terkait hukum perkawinan sirri online baik dalam hukum Islam maupun hukum positif serta dampak negatif yang timbulkan dimasa yang akan datang, membuka wawasan masyarakat yang ada di lingkungan mushalla Nurul Mubin Jl. Adi Sucipto Batu 10 Perumahan Mutiara Bintan RT.08/ RW 01, Kelurahan Pinang Kencana, Kecamatan Tanjung Pinang Timur, Kota Tanjungpinang tentang SE Dirjen Bimas Islam No. P-003 serta regulasi terkait pentingnya untuk mengikuti himbauan pemerintah agar calon pengantin dapat menunggu dan bersabar hingga pelaksanaan pernikahan dibuka kembali. Dan menyadarkan masyarakat bahwa perkawinan sirri sangat merugikan kaum perempuan beserta masa depan anak yang terlahir dari perkawinan tersebut.

Karena dampak negatif yang ditimbulkan sirri online sangatlah banyak selain merendahkan kaum perempuan karena nikah sirri dijadikan komoditas yang terang-terangan menyebutkan lelang keperawanan yang dipromosikan secara online, juga berpotensi memunculkan perbuatan melawan hukum seperti melegalkan perzinaan, perselingkuhan, hingga poligami. Selain perkawinan sirri online juga tidak tercatat di KUA, perkawinan tersebut juga mengancam status anak seperti wali, akte kelahiran, juga hak warisnya, melemahnya ketahanan keluarga, serta berdampak negatif bagi administrasi kependudukan. Selain itu diadakannya kegiatan ini juga diharapkan diimplementasikan dalam kehidupan masyarakat setempat khususnya sehingga menjadi masyarakat yang sadar hukum dan berperilaku sesuai aturan hukum yang berlaku. 
Perkawinan sirri online dan dampaknya sangat merugikan kaum perempuan dan anak yang terlahir dari perkawinan tersebut. Oleh karena itu, himbauan kepada pemerintah khususnya Kementerian Agama untuk melakukan serangkaian kegiatan dengan melibatkan agamawan untuk mencegah maraknya praktik nikah online. Peran penting lembaga hukum dapat memberikan hukuman yang tegas kepada pelaku nikah sirri online.

Pemerintah pusat dan pemerintah daerah harusnya bersinergi dalam upaya melakukan tindakan preventif terhadap praktik ini. Kementerian Pendidikan dan Kementerian Pemberdayaan Perempuan dan Anak bisa bekerja sama dalam memberikan edukasi terkait hal tersebut sehingga dapat memproteksi diri mereka. Kemenristekdikti juga perlu mendorong aktif Perguruan Tinggi agar memiliki program yang memiliki konsen terhadap perempuan dan anak.

\section{Ucapan Terimakasih}

Suksesnya acara penyuluhan ini tidak terlepas dari peran dan dukungan pihak-pihak yang terlibat yang telah memberikan dukungan baik dalam bentuk materil maupun moril. Terimakasih kepada Pusat Penelitian dan Pengabdian Masyarakat (PPPM) Sekolah Tinggi Agama Islam Sultan Abdurrahman Kepulauan Riau, Ketua Sekolah Tinggi Agama Islam Sultan Abdurrahman Kepulauan Riau, Ketua prodi Hukum Keluarga Islam, Bapak Dr. Muhammad Faisal dan Bapak Aris Bintania selaku reviewer yang telah banyak memberikan sumbangsih pemikiran demi meningkatkan kualitas pengabdian ini baik secara teoritis maupun emperik, jama'ah mushalla Nurul Mubin Jl. Adi Sucipto Batu 10 Perumahan Mutiara Bintan RT.08/ RW 01, Kelurahan Pinang Kencana, Kecamatan Tanjung Pinang Timur, Kota Tanjungpinang khususnya bapak Suherman selaku ketua RT, serta para dosen pengabdi.

\section{Referensi}

Abdurrahman, Kompilasi Hukum Islam di Indonesia, Jakarta: Akademika Presindo, 1992

Faruk, Nanang Husni, Analisis Hukum Islam Terhadap Pasal 29 Ayat 2 Kompilasi Hukum Islam (KHI)

Tentang Qabul Nikah Yang diwakilkan, Skripsi Fakultas syari'ah, IAIN Walisongo Semarang, 2008

Harahap, M. Yahya, Pengadilan Agama dan Kompilasi Hukum Islam Dalam Tata Hukum Indonesia. Yogyakarta: UII Press, 1993

Kuzairi, Achmad, Nikah Sabagai Perikatan, Raja Grafindo Persada, Cet. 1, Jakarta. 1995

Mughniyah, Muhammad Jamal, Fiqih lima mazhab: Ja'fari, Hanafi, Maliki, Syafi'I, Hambali, penerjemah, Masykur A.B, Afif Muhammad, dkk. Jakarta: Lentera, 2010

Nuruddin, Amir, Azhari Akmal Tarigan, Hukum Perdata Islam Di Indonesia (Studi KritisPerkembangan Hukum Islam dari Fikih, UU No. 1/1974 Sampai KHI). Jakarta: Kencana Prenada Media Group, 2004.

Rosyada, Dede, Hukum Islam dan Pranata Sosial, Jakarta; Rajawali Pres, 1993.

Shomad, Abd, Hukum Islam: Penormaan Prinsip Syariah Dalam Hukum Indonesia. Jakarta: Kencana, 2010

Tim Redaksi Fokus Media, Kompilasi Hukum Islam. Bandung: Fokus Media, 2007.

Undang-Undang Nomor 1 Tahun 1974 Tentang Perkawinan

Winarno, Ifan Tri, Pertimbangan Hakim Dalam Penggunaan Media Sosial Sebagai Alat Bukti Dalam Perkara Pidana Di Pengadilan Negeri Yogyakarta, Skripsi Fakultas syari'ah dan hukum, UIN Sunan Kalijaga Yogyakarta, 2014.

Zahrah, Abu, Al-Ahwal Al-Syakhshiyyah. Qahirah: Dar al-Fikr al-'Arabi, 1957.

Zaidan, Abdul Karim, Al-Madkhal li Dirasatisy-Syari'atil-Islamiyyati, Jakarta: Robbani Press, 2008. 